\title{
Dielectric Based Sensing System for Banana Ripeness Assessment
}

\author{
D. Jamaludin, S. Abd Aziz, and N. U. A. Ibrahim
}

\begin{abstract}
Banana is an extremely perishable fruit thus post-harvest quality process changes quickly. Conventional banana ripeness assessment include sorting and grading based on human visual evaluation, ethylene hormone treatment, firmness check by penetrometer and soluble solid content measurement using refractometer are not effective to give uniform and quick result. Dielectric spectroscopy has been applied in agricultural materials as it offers relatively inexpensive assessment, nondestructive, fast and easy to operate system. In ripeness assessment, the magnitude phase of impedance value will increase with ripening stages over certain frequency. This study showed that impedance measurement was able to differentiate the unripe, ripe and overripe banana over the frequency of $20.1 \mathrm{kHz}$ to $30.1 \mathrm{kHz}$. Soluble solid content (SSC) of banana was determined by developed model at the frequency of $21.1 \mathrm{kHz}$.
\end{abstract}

Index Terms-Banana ripeness, dielectric, impedance, soluble solid content.

\section{INTRODUCTION}

Banana (Musa paradisiaca L.) is one of the most widely cultivated fruit in Malaysia. This crop ranked second in terms of production area and fourth in export revenue based on the balance of trade figures. Fifteen percent of the banana produced is exported valued at more than RM 30 million [1]. Bananas start to ripen seven days after harvest and fully ripe in two days if they are stored at room temperature [2]. The sugar content indicates the best time for the fruit to be marketable. For bananas, the relationship between the sugar content and the peel color changes is parallel. Currently, ethylene gas control has been used as ripening treatment for bananas by the trained laborers [3]. Ethylene is a plant hormone that plays an important role in decreasing the storage life of fruits and vegetables [4]. However, this method is not always successful in bringing the uniformed ripening of banana fruits because of its lacking monitoring system. Firmness is a very good indicator in determining the quality of products, and it has been used to measure maturity and ripeness of fruit [5]. Usually, a penetrometer is used to measure firmness of fruits and it is a destructive method. Peel color is considered as a good indicator of banana ripeness as

Manuscript received August 9, 2013; revised October 21, 2013. This work was supported in part by the Ministry of Higher Education and Universiti Putra Malaysia.

D. Jamaludin is with the Faculty of Engineering Universiti Putra Malaysia (e-mail: dyna1401@yahoo.com).

S. Abd Aziz was with Universiti Putra Malaysia. She is now the head department of Department of Biological \& Agricultural Engineering, (e-mail: suzana@eng.upm.edu.my).

N. U. A. Ibrahim is with the Department of Biological \& Agricultural Engineering, Universiti Putra Malaysia (e-mail: nurulatikah.ibrahim@gmail.com). the chlorophyll content in the peel reduces with banana ripening [6]. The first observable sign of ripening is a color change from green to yellow [7]. There are seven stages of banana color guide during ripening and retailers usually sell banana fruits when they are at stage six. Nevertheless, this method is based on human visual determination that can be imprecise and insufficient to assess the internal quality changes. Therefore, it is important to assess banana ripeness through an inexpensive, fast and non-destructive approach.

Dielectric spectroscopy is relatively a new method applied to agricultural produce. Dielectric parameters used to characterize materials are dielectric constant, permittivity, dielectric loss and impedance. The choice of parameters depends on the suitability of materials and equipment available. Dielectric is also used for studying the structures of organic and inorganic materials with wide and continuous frequency impedance measurement [8]. Stuart O. Nelson (2005) had studied the dielectric properties of nine types of fresh fruits and vegetable over the frequency range from $10 \mathrm{MHz}$ to $1.8 \mathrm{GHz}$ and over the temperature range from 5 to $65^{\circ} \mathrm{C}$ [9]. Further research was carried out to find correlation between soluble solids content, indicative of sweetness, and the permittivity of honeydew melons for quality sensing [10]. His research provided new information useful in evaluating dielectric properties of such agricultural products for quality sensing applications. There are several other studies on dielectric characterization such as using impedance to study cold acclimation of scot pine [11] and to predict density of watermelons [12]. Sirikulrat et al. (2008) demonstrated that the relative permittivity of fresh soybean decreases as the bean matures [13]. Since dielectric based sensing showed potential use in wide agricultural products, this research was done to study the dielectric characteristic of banana at different ripeness using impedance measurement. The impedance value is then was correlate with the soluble solid content (SSC) to develop model to predict SSC value based on impedance measurement for ripeness determination.

\section{MATERIALS AND METHODS}

\section{A. Banana Impedance Measurement}

Banana (Musa paradisiaca L.) fruits from Berangan variety were used in this experiment. Banana fruits were classified into three groups which were unripe, ripe and overripe with total of 30 samples in each group. An impedance analyzer board AD5933 with electrocardiogram (ECG) probe was used to measure impedance values of banana at three different groups of ripeness. The ECG probes detect and amplify the tiny electrical changes as it were attached on banana (Fig. 1). The impedance analyzer board was connected to the PC for data extraction and analysis. 
Magnitude and phase of the impedance were measured directly at frequency sweep from $100 \mathrm{~Hz}$ to $100 \mathrm{kHz}$. The impedance measurement was shown in the software and the data was downloaded into Microsoft Excel format.

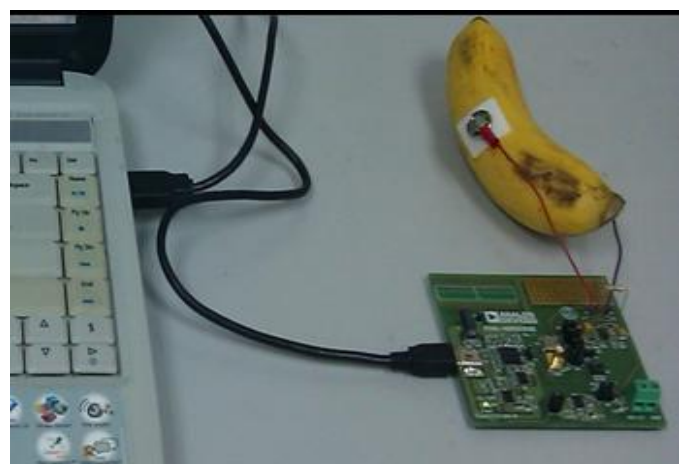

Fig. 1. ECG probes were attached to the banana.

\section{B. Soluble Solid Content (SSC) Measurement}

SSC is the quality indicator which currently requires samples from the internal tissues and is a destructive test. Sugar content increase steadily as banana ripens. Each banana was used to extract the fruit juice right after the electrical impedance measurement. Sugar content was measured by using a Pocket Refractometer PAL- $\alpha$ (Atago Co., Ltd). Ten grams of flesh was sampled from a whole banana (along length of fruit). The sample was macerated and the tissue was homogenized with $40 \mathrm{ml}$ of distilled water, using a hand mixer. A drop of the concentration was then placed on the prism glass of the refractometer to obtain the Brixpercentage that represents the SSC in the banana (Fig. 2). SSC were measured with three replications for each sample.

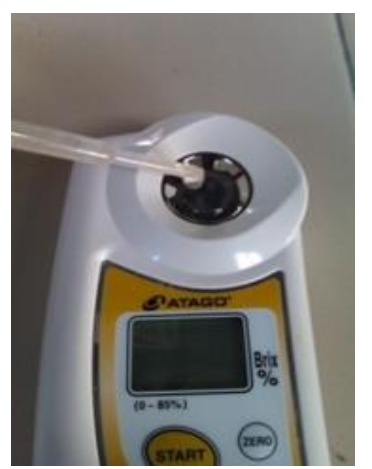

Fig. 2. SSC measurement by pocket refractometer.

\section{RESULTS AND DISCUSSION}

\section{A. Impedance Measurement of Banana from Berangan Variety at Different Ripeness}

Fig. 3 shows a negative linear relationship between impedance versus frequency at three stages of ripeness. Differences between the ripeness groups of banana can be seen clearly and it is noticed that the best frequency to differentiate the impedance value between the ripeness groups is between $20.1 \mathrm{kHz}$ and $30.1 \mathrm{kHz}$ with the value between $9.99 \mathrm{k} \Omega$ to $10.06 \mathrm{k} \Omega$. The unripe banana has higher impedance value than ripe and overripe banana. This result is parallel with theory as unripe banana has lower moisture content and soluble solid content therefore, it has higher impedance value.

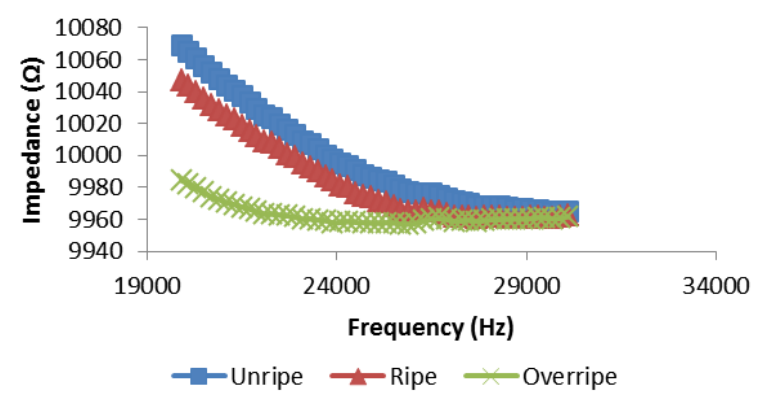

Fig. 3. Impedance variations for different ripening stages at frequency $19 \mathrm{kHz}$ to $30.1 \mathrm{kHz}$.

These three ripening groups were analyzed using ANOVA to evaluate on significant difference between ripening stages. It is apparent from these ANOVA result that there is significant difference between ripeness groups of banana using impedance measurement at $p$-value $=7.92 \mathrm{E}-11$ (Table I).

TABLE I: STATISTICAL ANALYSIS USING ANOVA TO DIFFERENTIATE IMPEDANCE MEASUREMENT BETWEEN RIPENESS GROUPS

\begin{tabular}{cccccc}
\hline \multicolumn{6}{c}{ IMPEDANCE MEASUREMENT BETWEEN RIPENESS GROUPS } \\
\hline $\begin{array}{c}\text { ANOVA } \\
\text { Variation }\end{array}$ & $S S$ & $d f$ & $F$ & p-value & F crit \\
\hline Between Groups & 29851.58 & 2 & 27.27 & $7.92 \mathrm{E}-11$ & 3.056 \\
Within Groups & 82102.57 & 150 & & & \\
Total & 111954.1 & 152 & & & \\
\hline
\end{tabular}

\section{B. SSC Measurement of Banana at Different Ripeness}

This experiment was carried out by batch and each ripeness group has 3 batches. One batch consists of ten fingers of banana. Results from the SSC measurement using pocket refractometer shows that SSC of banana increased as it reached the ripening stage. The SSC value increased from unripe to overripe (Table II). Most of the SSC is sugar so that during ripening, the starch of banana is converted into sugar; therefore SSC increased with ripening stage (Table II). SSC is an important trait of hydrolysis of starch into soluble sugars such as glucose, sucrose and fructose [7].

TABLE II: AVERAGE SSC VALUE AT DIFFERENT RIPENESS GROUPS

\begin{tabular}{|c|c|}
\hline $\begin{array}{c}\text { Average SSC value } \\
\text { (\% Brix) }\end{array}$ & Ripeness groups \\
\hline 0.47 & Unripe 1 \\
\hline 0.49 & Unripe 2 \\
\hline 0.68 & Unripe 3 \\
\hline 3.51 & Ripe 1 \\
\hline 3.54 & Ripe 2 \\
\hline 3.63 & Ripe 3 \\
\hline 4.38 & Overripe 1 \\
\hline 4.58 & Overripe 2 \\
\hline 5.03 & Overripe 3 \\
\hline
\end{tabular}

ANOVA was used to analyze these SSC value at every ripening stages (unripe, ripe and overripe) to confirm that these groups are significantly different. Result in Table III indicates that there is significant difference between ripeness groups of banana for SSC measurement at $p$-value $=8.1 \mathrm{E}-07$. 
Therefore, SSC value can be used as indicator of banana ripeness to correlate with impedance measurement.

TABLE III: STATISTICAL ANALYSIS USING ANOVA TO DIFFERENTIATE SSC VALUES FOR DIFFERENT RIPENESS GROUPS

\begin{tabular}{lccccc}
\hline ANOVA & & & & & \\
\hline $\begin{array}{l}\text { Source of } \\
\text { Variation }\end{array}$ & $S S$ & $d f$ & $F$ & $p$-value & $\begin{array}{c}F \\
\text { critical }\end{array}$ \\
\hline $\begin{array}{l}\text { Between } \\
\text { Groups }\end{array}$ & 27.244 & 2 & 318.856 & $8.1 \mathrm{E}-07$ & 5.143 \\
$\begin{array}{l}\text { Within } \\
\text { Groups }\end{array}$ & 0.256 & 6 & & & \\
Total & 27.501 & 8 & & & \\
\hline
\end{tabular}

\section{Correlation between Impedance Measurement and SSC Measurement of Banana}

Impedance measurement was found to have differences between three ripeness groups over the frequency of $20.1 \mathrm{kHz}$ to $30.1 \mathrm{kHz}$ with the impedance measurement at the range of $9.99 \mathrm{k} \Omega$ to $10.06 \mathrm{k} \Omega$. From this frequency, impedance measurement versus SSC measurement was plotted. Graph in Fig. 3 shows that, when SSC increase impedance decreased.

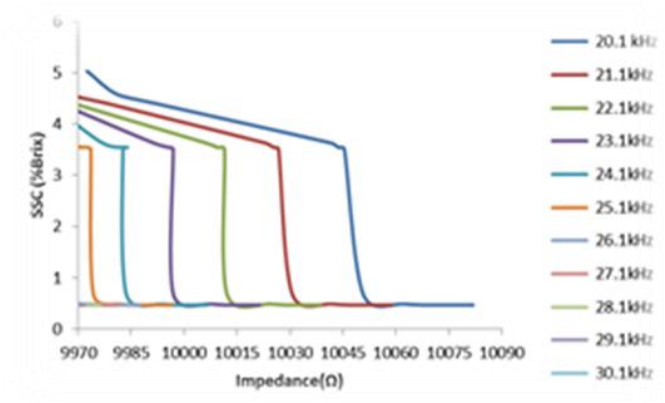

Fig. 3. Correlation between SSC measurements with impedance measurements at the frequency over $20.1 \mathrm{kHz}$ to $30.1 \mathrm{kHz}$.

\section{Prediction of SSC Value Using Linear Regression Models}

A good model should have a low Root Mean Square Error (RMSE). It is a frequently used measure of the difference between values predicted by a model and the values actually observed from real situation.Model that has the lowest RMSE $(0.769 \%$ Brix) was found at $21.1 \mathrm{kHz}$ (Table IV).

TABLE IV: RMSE AT THE FREQUENCY OF 20.1KHZ TO 24.1KHZ IN MODEL DEVELOPMENT

\begin{tabular}{|c|c|c|}
\hline Frequency $(\mathbf{k H z})$ & Linear regression model & $\begin{array}{c}\text { RMSE } \\
(\boldsymbol{\%} \text { Brix })\end{array}$ \\
\hline 20.1 & $y=-0.041 x+413.6$ & 1.258 \\
\hline 21.1 & $y=-0.046 x+463.8$ & 0.769 \\
\hline 22.1 & $y=-0.054 x+546.1$ & 1.973 \\
\hline 23.1 & $y=-0.069 x+694.4$ & 0.895 \\
\hline 24.1 & $y=-0.093 x+933.6$ & 1.131 \\
\hline
\end{tabular}

This indicates that banana ripeness can be predicted by impedance measurement at frequency of $21.1 \mathrm{kHz}$. A better model can be developed by using other data processing method such as partial least squares (PLS) and principal component regression (PCR) to develop models for predicting the SSC for more accurate rather than simple linear regression. A good linear correlation was found for
SSC versus impedance at frequency of $22.1 \mathrm{kHz}$ with $r^{2}$ $=0.7163$ (Fig. 4). This indicates that impedance can be used as attribute to determine SSC of banana.

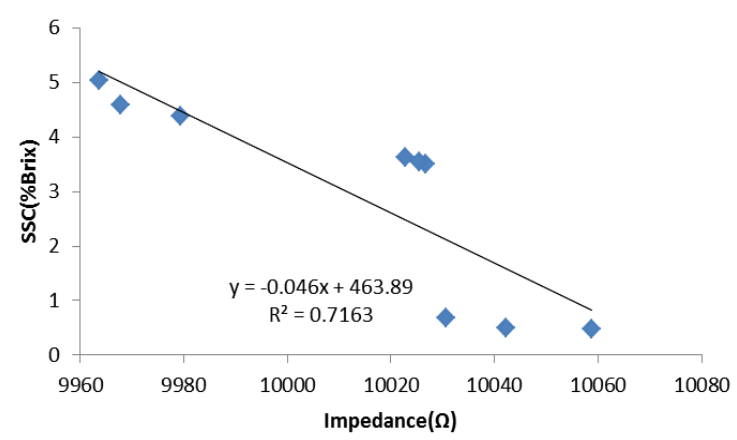

Fig. 4. Scatter plot of SSC versus impedance at frequency of $21.1 \mathrm{kHz}$.

\section{CONCLUSION}

The result from this study has shown that there is negative linear relationship between impedance and frequency. It also shows that unripe banana has higher impedance value than ripe and overripe banana. This relationship demonstrate that impedance measurement have potential in assessing banana fruit quality. It is suggested that future studies involved other parameter such as firmness, peel color changes and moisture content. Further data processing and model development using other data processing method such as PLS and PCR are suggested in order to get the better model with low RMSE.

\section{ACKNOWLEDGMENT}

The author would like to acknowledge Ministry of Higher Education and University Putra Malaysia for sponsoring her studies.

\section{REFERENCES}

[1] N. M. Hassan, "Enhancing the Malaysian banana industry: R\&D advancing banana and plantain R\&D in Asia and the Pacific," in Proc. The 3rd BAPNET Steering Committee, November 23-26, 2004, vol. 13, pp. 89-96.

[2] J. Mortan, "MUSACEAE banana," Fruits of Warm Climates, Creative Resource System, Inc., Box 890, Winterville, N. C. 28590, pp. 29-46, 1987.

[3] M. Soltani, R. Alimardani, and M. Omid, "Prediction of banana quality during ripening stage using capacitance sensing system," Australian Journal of Crop Science, vol. 4, no. 6, pp. 443-447, 2013.

[4] J. H. Bower, W. V. Biasi, and E. J. Mitcham, "Effect of ethylene in the storage environment on quality of 'bartlett pears'," Postharvest Biology and Technology, vol. 28, pp. 371-379, 2003.

[5] E. Hoehn, F. Gasser, B. Guggenbuhl, and U. Kunsch, "Efficacy of instrumental measurements for determination of minimum requirements of firmness, soluble solids, and acidity of several apple varieties in comparison to consumer expectations," Postharvest Biology and Technology, vol. 27, pp. 27-37, 2003.

[6] M. Li, D. C. Slaughter, and J. F. Thompson, "Optical chlorophyll sensing system for banana ripening," Postharvest Biology and Technology, vol. 12, pp. 273-283, 1997.

[7] J. Marriott, M. Robinson, and S. K. Karikari, "Starch and sugar transformation during the ripening of plantains and bananas," Journal of Science, Food and Agriculture, pp. 1021-1026, 1981.

[8] L. Ragni, P. Gradari, A. Berardinelli, A. Giunchi, and A. Guarnieri, "Predicting quality parameters of shell eggs using a simple technique based on the dielectric properties," Biosystems Engineering, vol. 94, no. 2, pp. 255-262, 2006.

[9] S. O. Nelson, "Dielectric spectroscop of fresh fruits and vegetables," U.S. Department of Agriculture, Agricultural Research Service, Athens, GA, 30604-5677, USA, 2005.

[10] S. O. Nelson, S. Trabelsi, and S. J. Kays, "Dielectric spectroscopy of honeyder melons for quality sensing," Sorrento, Italy, pp. 24-27, 2006. 
[11] T. Repo, G. Zhang, A. Ryyppo, and R. Rikala, "The electrical impedance spectroscopy of scots pine (Pinus Sylvestris L.) shoots in relation to cold acclimation," Journal of Experimental Botany, vol. 51, pp. 2095-2107, 2000.

[12] K. Kato, "Electrical density sorting and estimation of soluble solids content of watermelon," J. Agric. Eng Res. vol.67, pp. 161-170, 1997.

[13] K. Sirikulrat and N. Sirikulat, "Dielectric properties of different maturity soybean," KMITL Sci. J., vol. 8, no. 2, 12-18

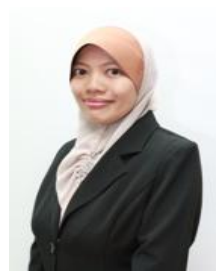

Diyana Jamaludin is from Malaysia. She received Bachelor of Engineering in Biological \& Agricultural from Universiti Putra Malaysia in 2005. She then pursued her Master Degree at the same university and obtained her Master Degree of Bioenvironmental Engineering in 2010. Currently, she is a Ph.D. student in Faculty of Engineering, Universiti Putra Malaysia and working on research related to dielectric and impedance spectroscopy in agricultural materials.

She is attached with Department of Biological \& Agricultural Engineering UPM as a tutor and currently she is on her study leaves. Her previous work and research was also on GIS and controlled environment. Ms. Diyana is a member of ASABE, MSAE and was a registered member of IEM. Her current work "Dielectric Based Measurement System for Agricultural Materials" had received a gold medal award in I-ENVEX, Malaysia.

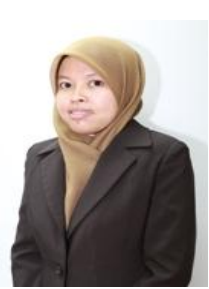

Samsuzana Abd Aziz is from Malaysia. She received Bachelor of Engineering in Electrical Telecommunication from Universiti Teknologi Malaysia in 2002 and then pursued her master and Ph.D. in Agricultural Engineering at Iowa State University, USA.

Currently, she is in the head of Department of Biological \& Agricultural Engineering, Universiti Putra Malaysia and her research interests are mainly on Agricultural and Biosystems Instrumentation, and GIS.

Dr. Samsuzana is the vice president of MSAE, treasurer of IEEE GOLD Affinity Group and member of ASABE, and BEM. She had received many international and national awards for her respective research work.

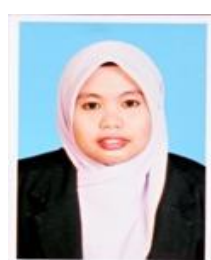

Nur Ul Atikah Ibrahim is from Malaysia. She received Bachelor of Engineering in Agricultural \& Biosystem from Universiti Putra Malaysia in 2013. She also has a diploma in Mechanical Engineering (Agriculture) in 2009.

Nur Ul Atikah is an active student at her faculty and college at UPM. She also received gold medal award in I-ENVEX Malysia. 